\title{
Bio-monitoring of Western Ghats Stream using Aquatic insects
}

\author{
G.L. Priyanka and G. Prasad \\ Department of Zoology, University of Kerala \\ Kariavattom, Thiruvananthapuram-695 581, India \\ E-mail: priyankagl09@gmail.com
}

\begin{abstract}
In this study health of the Kallar stream and its tributaries originating from Western Ghats in Kerala using aquatic insects as indicators was assessed. Two-year sampling of aquatic insects was done on a monthly basis from five different sites. Insects were collected and identified using the methodology of Rapid Bio-assessment Protocol. A total of 29372 individuals belonging to 9 orders and 61 families of aquatic insects were collected and identified from the selected study sites. Highest number of aquatic insect was obtained in the site 5 (7531) and the lowest number was observed in site 3 (4571). All richness measures were maximum in site 5 and the minimum in site 3 . In addition to that the biotic indices like Family Biotic Index (FBI), Biological Monitoring Working Party (BMWP) Score and Average Score per Taxon (ASPT) also show that water quality of site 5 is free from organic pollution compared to the other sites.
\end{abstract}

Keywords: Aquatic insects, Biomonitoring, Family Biotic Index, Indicators, Kallar stream

Aquatic insects have been used as bio-indicators and are amongst the most frequently used groups in biological assessment of water quality worldwide (Bunn et al 2010, Chon et al 2013, Kamal and Kumar 2021). They play important ecological roles in keeping freshwater ecosystems functioning properly (Choudhary and Janak 2015). Aquatic insects may have considered model organisms in analyzing the structure and function of the freshwater ecosystem because of their high abundance, high birth rate with short generation time, large biomass and rapid colonization of freshwater habitats (Solanki and Shukla 2015, Pandian et al 2019). Rapid bio-assessment approaches are meant to provide an initial screening of water bodies for further investigations (Mandaville 2002). Family level identification is useful for one-time assessment of water quality in a specific area, or in the ranking of sites for additional study. Variations in the diversity of aquatic insects may be attributed to the degree of anthropogenic interference in the ecological balance of fresh water bodies, where anthropogenic activities of humans associated with a reduction in diversity of aquatic insect communities (Popoola and Otalekor 2011, Wahizatul et al 2011, Abhijna et al 2012, Adu and Oyeniyi 2019). The present study is an attempt to evaluate the water quality of Kallar stream and its tributaries using aquatic insects. This data will be helpful as a yardstick to assess the water quality in the years to come.

\section{MATERIAL AND METHODS}

Study area: The study stream Kallar is a perennial river located near Ponmudi in Thiruvananthapuram district, Kerala, part of the Southern tip of Western Ghats. 'Kallar' literally means stony river. It forms the upper course of Vamanapuram River, part of Neyyar Wildlife Sanctuary. It originates from Chemmunji Mottai, a mountain peak in the Western Ghats at an elevation of $1860 \mathrm{~m}$ above MSL. In this study five collection sites were selected were- DarphaKalungu (S1- $8^{\circ} 40^{\prime} 42$ se N, $77^{\circ} 04^{\prime} 02$ se E), Pottanchira (S2$8^{\circ} 41^{\prime} 31$ se N, $77^{\circ} 03^{\prime} 09$ se E), Kaliyikkal (S3- 8 $40^{\prime} 16$ se N, $77^{\circ} 06^{\prime} 04$ se E), Meenmutti (S4- $8^{\circ} 42^{\prime} 36$ se N, $77^{\circ} 07^{\prime} 41$ se E) and main Kallar (S5- $8^{\circ} 43^{\prime} 42$ se N, $77^{\circ} 07^{\prime} 37$ se E) (Table 1 , Fig. 1). From these the first four sites are the tributaries of Kallar stream and the fifth one is the main stream. The sites are chosen based on their location relative to habitat availability, land use pattern and human intervention. At each sampling locality, a stretch of $100 \mathrm{~m}$ area was chosen for collection of samples.

The aquatic insect sampling was done for two years (January 2012- December 2013) based on the methodology of Rapid Bio-assessment Protocol (Barbour et al 1999). Aquatic insects were collected by using kick net $\left(1 \mathrm{~m}^{2}\right.$ area, mesh size $200 \mu \mathrm{m}$ ) and D-frame net (mesh size $50 \mu \mathrm{m}$ ). The organisms trapped within the net were collected without any damage using fine forceps and brush and preserved in $70 \%$ alcohol. In the laboratory, the immature insects were sorted, identified and counted. Family level identifications were made by using available references (Mc Cafferty and Provonsha 1981, Morse et al 1984, Yule and Sen 2004, Subramanian and Sivaramakrishnan 2007). All the taxa 
encountered during the study were assigned a habit (mode of existence) and functional feeding categories with the help of published references (Resh and Rosenberg 1984, Pringle et al 1988, Merrit and Cummins 1996). Benthic metrics like richness measures (taxa), composition measures (\%), feeding measures (\%) and habit measures were calculated for each site (Barbour et al 1999). In addition to that the biotic indices like Family Biotic Index (FBI), Biological Monitoring Working Party (BMWP) Score and Average Score Per Taxon (ASPT) values were also measured.

Family biotic index (FBI): The biotic index was originally developed by Hilsenhoff (1982) to provide a single 'tolerance value' which is the average of the tolerance values of all species within the benthic arthropod community. The biotic index was subsequently modified to the family-level with tolerance values ranging from 0 (very intolerant) to 10 (highly tolerant) based on their tolerance to organic pollution, creating the Family Biotic Index (FBI) (Hilsenhoff 1988). FBI was further developed by the State of New York to include

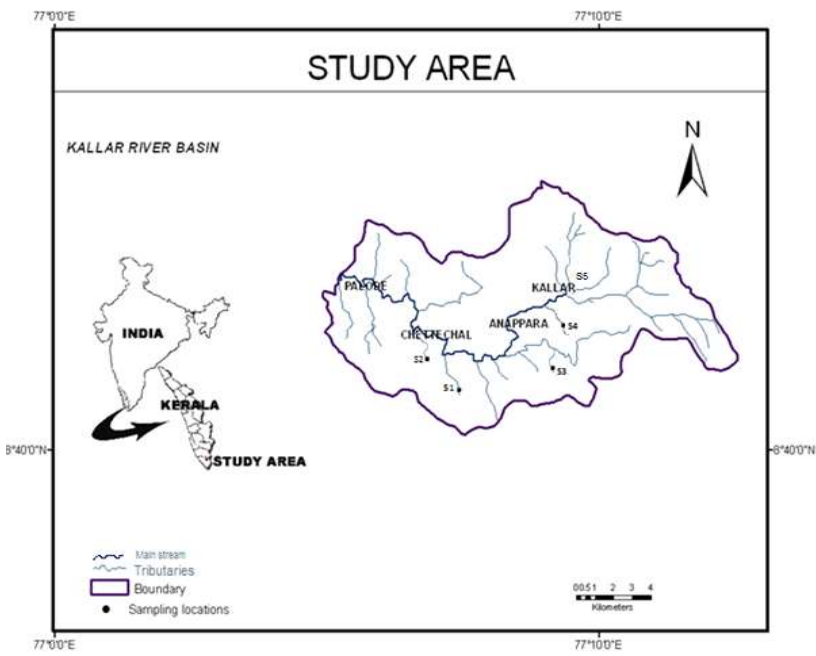

Fig. 1. Location site other macroinvertebrates for the use of the U.S. EPA Rapid Bio-assessment Protocol II (Plafkin et al 1989, Bode 1991).

FBI was calculated as:

$\mathrm{FBI}=\mathrm{n}_{\mathrm{i}} \mathrm{t}_{\mathrm{i}}$

$\mathrm{N}$

Where, $\mathrm{n}_{\mathrm{i}}=$ number of organisms in each family

$t_{i=}$ tolerance value of that family

$\mathrm{N}=$ total number of insects

Biological monitoring working party score (BMWP): The biological monitoring working party score (BMWP) provides single values, at the family level, representative of the organisms' tolerance to pollution. The greater their tolerances towards pollution, the lower the BMWP score. To reflect conditions within North America, Mackie (2001) has modified this index. BMWP was calculated by adding the

Table 2. Evaluation of water quality using the family-level biotic index

\begin{tabular}{lll}
\hline FBI & Water quality & Degree of organic pollution \\
\hline $0.00-3.75$ & Excellent & Organic pollution unlikely \\
3.76-4.25 & Very good & Possible slight organic pollution \\
$4.26-5.00$ & Good & Some organic pollution probable \\
$5.01-5.75$ & Fair & Fairly substantial pollution likely \\
$5.76-6.50$ & Fairly poor & Substantial pollution likely \\
$6.51-7.25$ & Poor & Very substantial pollution likely \\
$7.26-10.00$ & Very poor & Severe organic pollution likely \\
\hline
\end{tabular}

Table 3. Evaluation of water quality using the average score per taxon (ASPT)

\begin{tabular}{ll}
\hline ASPT value & Water quality assessment \\
\hline$>6$ & Clean water \\
$5-6$ & Doubtful quality \\
$4-5$ & Probable moderate pollution \\
$<4$ & Probable severe pollution \\
\hline
\end{tabular}

Table 1. Characteristics of Kallar stream and its tributaries

\begin{tabular}{|c|c|c|c|c|c|}
\hline Characteristics & Site 1 & Site 2 & Site 3 & Site 4 & Site 5 \\
\hline Name of site & Darpha-Kalungu & Pottanchira & Kaliyikkal & Meenmutty & Main Kallar \\
\hline Latitude & $8^{\circ} 40^{\prime} 42$ se $N$ & $8^{\circ} 41^{\prime} 31$ se $N$ & $8^{\circ} 40^{\prime} 16$ se $N$ & $8^{\circ} 42^{\prime} 36$ se $N$ & $8^{\circ} 43^{\prime} 42$ se $N$ \\
\hline Longitude & $77^{\circ} 04^{\prime} 02$ se $\mathrm{E}$ & $77^{\circ} 03^{\prime} 09$ se $\mathrm{E}$ & $77^{\circ} 06^{\prime} 04$ se $\mathrm{E}$ & $77^{\circ} 07^{\prime} 41$ se $\mathrm{E}$ & $77^{\circ} 07^{\prime} 37$ se $\mathrm{E}$ \\
\hline Altitude(m) & 111 & 105 & 116 & 156 & 227 \\
\hline Subsystem & Perennial & Perennial & Perennial & Perennial & Perennial \\
\hline Vegetation & Trees and grass & Trees and grass & Trees and grass & Trees and grass & Trees and grass \\
\hline Land use & Plantations & Plantations & Residential & Forest & Forest \\
\hline Canopy & Open & Open & Open & Shaded & Shaded \\
\hline Turbidity & Clear & Clear & Clear & Clear & Clear \\
\hline Human settlement & Present & Present & Present & Present & Absent \\
\hline
\end{tabular}


Table 4. Aquatic insects collected from the study sites

\begin{tabular}{|c|c|c|c|c|c|c|c|}
\hline Family & Site 1 & Site 2 & Site 3 & Site 4 & Site 5 & $\begin{array}{c}\text { Tolerance } \\
\text { values }\end{array}$ & $\begin{array}{l}\text { BMWP score } \\
\text { value }\end{array}$ \\
\hline \multicolumn{8}{|l|}{ Ephemeroptera } \\
\hline Leptophlebiidae & 932 & 1028 & 380 & 631 & 461 & 2 & 10 \\
\hline Ephemeridae & 24 & 24 & 17 & 14 & 29 & 4 & 10 \\
\hline Potamanthidae & 9 & 0 & 0 & 0 & 8 & 4 & 10 \\
\hline Ephemerellidae & 2 & 4 & 0 & 4 & 8 & 1 & 10 \\
\hline Tricorythidae & 0 & 0 & 0 & 0 & 2 & 4 & \\
\hline Caenidae & 286 & 207 & 138 & 37 & 36 & 7 & 7 \\
\hline Heptageniidae & 25 & 17 & 7 & 717 & 1230 & 4 & 10 \\
\hline Baetidae & 300 & 245 & 177 & 184 & 129 & 4 & 4 \\
\hline \multicolumn{8}{|l|}{ Plecoptera } \\
\hline Perlidae & 216 & 297 & 49 & 695 & 1046 & 1 & 10 \\
\hline \multicolumn{8}{|l|}{ TRICHOPTERA } \\
\hline Hydropsychidae & 850 & 1312 & 845 & 1360 & 1890 & 4 & 5 \\
\hline Polycentropodidae & 6 & 21 & 5 & 97 & 130 & 6 & 7 \\
\hline Psychomyeidae & 0 & 3 & 0 & 0 & 4 & 2 & 8 \\
\hline Xiphocentropodidae & 0 & 2 & 0 & 0 & 4 & & \\
\hline Calamoceratidae & 4 & 2 & 2 & 1 & 7 & 3 & \\
\hline Odontoceridae & 2 & 2 & 2 & 4 & 8 & 0 & 10 \\
\hline Philopotamidae & 0 & 2 & 5 & 150 & 189 & 3 & 8 \\
\hline Stenopsychidae & 0 & 0 & 0 & 30 & 58 & & \\
\hline Brachycenridae & 4 & 4 & 4 & 18 & 17 & 1 & 10 \\
\hline Lepidostomatidae & 2 & 0 & 0 & 9 & 50 & 1 & 10 \\
\hline \multicolumn{8}{|l|}{ Odonata } \\
\hline Gomphidae & 426 & 1044 & 374 & 320 & 683 & 1 & 8 \\
\hline Cordullidae & 70 & 17 & 137 & 79 & 8 & 5 & 8 \\
\hline Libellulidae & 240 & 31 & 259 & 42 & 12 & 9 & 8 \\
\hline Macromidae & 7 & 20 & 37 & 10 & 4 & 3 & \\
\hline Coenagrionidae & 14 & 18 & 24 & 13 & 15 & 9 & 6 \\
\hline Platycnemididae & 51 & 3 & 94 & 11 & 24 & & 6 \\
\hline Platystictidae & 14 & 18 & 24 & 13 & 42 & & \\
\hline Protoneuridae & 86 & 14 & 75 & 9 & 7 & & \\
\hline Lestidae & 13 & 7 & 14 & 4 & 12 & 9 & 8 \\
\hline Chlorolestidae & 70 & 79 & 156 & 95 & 123 & & \\
\hline Calopterygidae & 207 & 110 & 76 & 84 & 18 & 5 & 8 \\
\hline Chlorocyphidae & 8 & 7 & 14 & 9 & 18 & & \\
\hline Euphaidae & 99 & 164 & 180 & 80 & 234 & 4 & \\
\hline \multicolumn{8}{|l|}{ Hemiptera } \\
\hline Aphelocheridae & 11 & 8 & 9 & 73 & 12 & & 10 \\
\hline Nepidae & 34 & 16 & 11 & 8 & 0 & 7 & 5 \\
\hline Belostomatidae & 178 & 4 & 27 & 0 & 5 & 9 & 5 \\
\hline Naucoridae & 624 & 166 & 932 & 330 & 215 & 5 & 5 \\
\hline Notonectidia & 3 & 2 & 0 & 0 & 0 & 6 & 5 \\
\hline
\end{tabular}


Table 4. Aquatic insects collected from the study sites

\begin{tabular}{|c|c|c|c|c|c|c|c|}
\hline Family & Site 1 & Site 2 & Site 3 & Site 4 & Site 5 & $\begin{array}{c}\text { Tolerance } \\
\text { values }\end{array}$ & $\begin{array}{l}\text { BMWP score } \\
\text { value }\end{array}$ \\
\hline Pleidae & 2 & 3 & 1 & 4 & 7 & 1 & 5 \\
\hline Vellidae & 80 & 103 & 21 & 92 & 2 & 6 & 5 \\
\hline Gerridae & 71 & 76 & 83 & 82 & 26 & 5 & 5 \\
\hline Hydrometridae & 10 & 0 & 0 & 0 & 0 & & \\
\hline \multicolumn{8}{|l|}{ Coleoptera } \\
\hline Hydroscaphidae & 13 & 5 & 8 & 5 & 0 & 7 & \\
\hline Dytiscidae & 313 & 130 & 100 & 59 & 17 & 5 & 5 \\
\hline Gyrinidae & 9 & 35 & 6 & 14 & 5 & 4 & 5 \\
\hline Amphizoidae & 0 & 9 & 4 & 3 & 14 & 1 & \\
\hline Hydraenidae & 75 & 104 & 37 & 46 & 11 & 5 & \\
\hline Elmidae & 9 & 51 & 12 & 64 & 80 & 4 & 5 \\
\hline Dryopidae & 2 & 5 & 8 & 28 & 45 & 5 & 5 \\
\hline Hydrophilidae & 21 & 15 & 45 & 46 & 13 & 5 & 5 \\
\hline Psephinidae & 7 & 6 & 21 & 163 & 281 & 4 & \\
\hline Sperchidae & 2 & 0 & 5 & 0 & 0 & & \\
\hline Scritidae & 0 & 0 & 6 & 0 & 0 & 5 & 5 \\
\hline \multicolumn{8}{|l|}{ Megaloptera } \\
\hline Corydalidae & 4 & 2 & 7 & 87 & 105 & 0 & 6 \\
\hline \multicolumn{8}{|l|}{ Lepidoptera } \\
\hline Pyralidae & 4 & 2 & 2 & 16 & 20 & 5 & \\
\hline \multicolumn{8}{|l|}{ Diptera } \\
\hline Tipulidae & 51 & 64 & 14 & 78 & 90 & 3 & 5 \\
\hline Ceratopogonidae & 12 & 38 & 19 & 26 & 23 & 6 & 4 \\
\hline Chironomidae & 4 & 6 & 17 & 5 & 6 & 6 & 2 \\
\hline Simulidae & 8 & 12 & 35 & 19 & 10 & 6 & 5 \\
\hline Tabanidae & 17 & 3 & 30 & 12 & 4 & 6 & 3 \\
\hline Athericidae & 13 & 7 & 14 & 159 & 24 & 2 & 6 \\
\hline Ephydridae & 5 & 4 & 2 & 4 & 10 & 6 & 4 \\
\hline Total & 5549 & 5578 & 4571 & 6143 & 7531 & & \\
\hline
\end{tabular}

individual scores of all families, and order Oligochaeta (Friedrich et al 1996), represented within the community.

Average score per taxon (ASPT): The average score per taxon (ASPT) represents the average tolerance score of all taxa within the community, and was calculated by dividing the BMWP by the number of families represented in the sample (Friedrich et al 1996). From this value, the water quality of each lake was assessed.

\section{RESULTS AND DISCUSSION}

Overall 29372 individuals belonging to 9 orders and 61 families of aquatic insects were collected and identified. From this, a total of 5549 individuals belonging to 54 families were collected from site 1, 5578 individuals of 54 families from site 2, 4571 individuals of 53 families from site 3, 6143 individuals of 52 families from site 4 and 7531 individuals of 61 families from site 5 (Table 4). Aquatic insects were mostly contributed by the immature stages. They were represented by the orders of Ephemeroptera, Plecoptera, Trichoptera, Odonata, Hemiptera, Coleoptera, Megaloptera, Lepidoptera and Diptera. Ephemeroptera was the most dominant order with the highest number of individuals $(24.89 \%)$ followed by Trichoptera, Odonata, Hemiptera and Plecoptera.

Highest number of aquatic insects was obtained in the site 5 (7531) and the lowest number was observed in site 3 (4571) (Table 4). The aquatic insects like Ephemeroptera, Plecoptera and Trichoptera are sensitive to environmental perturbations and occur in clean and well oxygenated waters 
Table 5. Benthic metrics of the aquatic insects from selected sites

\begin{tabular}{|c|c|c|c|c|c|c|}
\hline Category & Metrics (Taxa) & Site 1 & Site 2 & Site 3 & Site 4 & Site 5 \\
\hline \multirow[t]{5}{*}{ Richness measures } & Total number & 5549 & 5578 & 4571 & 6143 & 7531 \\
\hline & EPT & 2662 & 3170 & 1631 & 3951 & 5306 \\
\hline & Ephemeroptera & 1578 & 1525 & 719 & 1587 & 1903 \\
\hline & Plecoptera & 216 & 297 & 49 & 695 & 1046 \\
\hline & Trichoptera & 868 & 1348 & 863 & 1669 & 2357 \\
\hline \multirow[t]{5}{*}{ Composition measures (\%) } & EPT & 47.97 & 56.83 & 35.68 & 64.32 & 70.46 \\
\hline & Ephemeroptera & 28.44 & 27.34 & 15.73 & 25.83 & 25.27 \\
\hline & Trichoptera & 15.64 & 24.17 & 18.88 & 27.17 & 31.30 \\
\hline & Diptera & 1.98 & 2.40 & 2.87 & 4.93 & 2.22 \\
\hline & Chironomidae & 0.07 & 0.11 & 0.37 & 0.08 & 0.08 \\
\hline \multirow[t]{5}{*}{ Feeding measures (\%) } & Collector Filters & 11.84 & 19.36 & 14.87 & 20.63 & 23.56 \\
\hline & Scrapers & 18.89 & 18.27 & 12.16 & 20.50 & 22.29 \\
\hline & Collector-gatherers & 24.22 & 23.98 & 14.83 & 23.09 & 21.52 \\
\hline & Predators & 44.52 & 37.72 & 57.59 & 34.10 & 30.18 \\
\hline & Shredders & 0.53 & 0.67 & 0.55 & 1.68 & 2.44 \\
\hline \multirow[t]{2}{*}{ Habit measures } & Number of clingers & 3133 & 3353 & 2551 & 4717 & 6069 \\
\hline & Clingers (\%) & 35.70 & 41.10 & 38.10 & 53.10 & 64.60 \\
\hline FBI & & 4.2 & 3.22 & 4.42 & 3.4 & 3.16 \\
\hline BMWP & & 255 & 246 & 238 & 233 & 261 \\
\hline ASPT & & 6.38 & 6.31 & 6.26 & 6.47 & 6.53 \\
\hline
\end{tabular}

only. Among EPT taxa, Oder Plecoptera have long been as the most pollution intolerant of the aquatic insect orders compared to the other two groups in this category such as Ephemeroptera and Trichoptera (Ab - Hamid 2017). In our study the number of Plecoptera was found to be maximum site 5 and the minimum value was observed in site 3 . The Diptera was maximum in site 4 and the minimum in site 1. Diptera can be found in a clean stream to polluted streams (Abbasi et al 2020). The Chironomidae measures indicates that highest value was in site 3 and the lowest value in site 1. Family Chironomidae belongs to order Diptera is considered to be a pollution tolerant group may be due to the presence of hemoglobin pigment that helps them to collect oxygen directly from the atmosphere (Davason and Henry 2007).

The feeding measures like collector- filterers and shredders were highest in site 5 and the lowest in site 1 . The percent scrapers were maximum in site 5 and minimum in site 3 . The highest value of collector- gatherers was observed in site 1 and lowest in site 3 . The maximum predators were obtained in site 3 and the minimum in site 5 . The clingers were found to be maximum in site 5 and minimum in site 1 . Collector gatherers are more tolerant to disturbances because they exhibit generalist feeding habits, whereas shredders and scrapers are exhibited the highest level of feeding specialization because of that they are considered to be more sensitive to environmental disturbances (Min et al 2019).

Comparison of FBI throughout the study showed that the higher FBI value was at site 3 (4.54) indicating greater pollution due to the presence of highly tolerant taxa such as Libellulidae, Coenagrionidae, Lestidae and Chironomidae compared to other sites which shows less pollution. Lower FBI value was found in site 5 (3.14) and it is due to the large number of pollution intolerant taxa like Ephemerellidae, Perlidae, Odontoceridae, Brachycentridae, Lepidostomatidae and Corydalidae. In our study the value of FBI ranged between 3.16 to 4.42 that is excellent to good water quality conditions. Similar results were also observed by Marwein and Gupta (2018) in a small stream of Shillong, Meghalaya. The maximum BMWP score was reported from site 5 and minimum in Site 3 . This is because in site 5 the number of pollution intolerant families was high, while in site 3 pollution tolerant families are dominant. Low index value indicates the study area was physically disturbed and which results from the low abundance of aquatic organisms (Bhandarkar and Bhandarkar 2013). In study the highest ASPT score was reported in site 5 and lowest values observed in site 3 .

\section{CONCLUSION}

The biomonitoring based on aquatic insects played a 
significant role in assessing the environmental status of Kallar stream and its tributaries. The biotic index value of site 3 comes in the range of $4.26-5.00$, water quality is good but some organic pollution is possible here. The small scale human activities in site 3 are sufficient to produce some kind of organic pollution and to change the composition of aquatic insects during the period of observation. Rare specimens of habitat sensitive organisms such as Ephemeroptera, Plecoptera and Trichoptera still minimum in site 3 and maximum numbers were present in site 5 . In addition to that all the calculated benthic metrics revealed that the water quality of site 5 was good compared to the other four sites, i.e. tributaries. Routine monitoring and continuous investigations are required to keep the stream healthy in the future also. The rapid bio-assessment protocols are being applied in many countries with success and optimizing time and resources in sample methodologies. But there is lack thorough knowledge on the taxonomy and ecology of regional aquatic insects. Hence, more comprehensive investigations are needed to expand our knowledge on aquatic insect diversity, and then only and can assign tolerance value to the regional biota and to develop our own biotic index and metrics to evaluate water quality.

\section{ACKNOWLEDGEMENT}

The financial aid for the study has been given by the Kerala State Council for Science, Technology and Environment (KSCSTE), which is highly acknowledged.

\section{REFERENCES}

Abbasi M, Doosti S, Vatandoost $\mathrm{H}$ and Hosseini-Vasoukolaei $\mathrm{N}$ 2020 . Study on the fauna of aquatic insects in northwestern Iran. Journal of Arthropod-Borne Diseases 14 (1): 1.

Ab-Hamid S and Rawi CSM 2017. Application of aquatic insects (Ephemeroptera, Plecoptera and Trichoptera) in water quality assessment of Malaysian headwater. Tropical Life Sciences Research 28(2): 143.

Abhijna UG, Ratheesh R and Biju Kumar A 2013. Distribution and diversity of aquatic insects of Vellayani lake in Kerala. Journal of Environmental Biology 34(3): 605-611.

Adu BW and Oyeniyi EA 2019. Water quality parameters and aquatic insect diversity in Aahoo stream, southwestern Nigeria. The Journal of Basic and Applied Zoology 80(1): 15.

Barbour MT, Gerritsen J, Snyder BD and Stribling JB 1999. Rapid bioassessment protocols for use in streams and Wadeable rivers: Periphyton, benthic macroinvertebrates and fish. EPA841-B-99-002, US Environmental Protection Agency: Office of Water, Washington DC, second edition, p 299.

Bhandarkar SV and Bhandarkar WR 2013. A study on species diversity of benthic macro invertebrates in freshwater lotic ecosystems in Gadchiroli district Maharashtra. International Journal of Life Sciences 1:22-31.

Bode RW 1991. Quality assurance work plan for biological stream monitoring in New York State. New York Department of Environmental Conservation Technical Report, p 79.

Bunn SE, Abal EG, Smith MJ, Choy SC, Fellows CS, Harch BD, Kennard MJ and Sheldon F 2010. Integration of science and monitoring of river ecosystem health to guide investments in catchment protection and rehabilitation. Freshwater Biology 55 : 223-240.

Chon TS, Qu X, Cho WS, Hwang HJ, Tang H, Liu Y and Choi JH 2013. Evaluation of stream ecosystem health and species association based on multi-taxa (benthic macro invertebrates, algae, and microorganism) patterning with different levels of pollution. Ecological Informatics 17: 58-72.

Choudhary Aand Janakahi 2015. Diversity and distribution of aquatic insect population in Lakha banjara Lake, Sagar (MP), India. Journal of International Academic Research for Multidisciplinary 3(5): 367.

Davanson RCS and Henry R 2007. Composition and abundance of Chironomidae and Ephemeroptera in a lateral lake in the mouth zone of Paranapanema River in to Jurumirin Reservoir (State of Sao Paulo). Acia Limnologica Brasiliensia 19: 131-142.

Friedrich G, Chapman D and Beim A 1996. The Use of Biological Material in Water Quality Assessments: A Guide to the Use of Biota. Sediments and Water in Environmental Monitoring, 2nd ed. Chapman D (ed.). E. \& F.N. Spon, New York.

Hilsenhoff WL 1982. Using a biotic index to evaluate water quality in streams. Wisconsin Department of Natural Resources Technical Bulletin, 132, p 22.

Hilsenhoff WL 1988. Rapid field assessment of organic pollution with a family level biotic index. Journal of the North American Benthological Society 7: 66-68.

Kamal S and Kumar RS 2021. Assessment of biological water quality based on functional feeding groups of benthic Macroinvertebrates: A case study of Pampa River. Indian Journal of Ecology 48(3): 837-841.

Mackie GL 2001. Applied Aquatic Ecosystem Concepts. Kendall/Hunt Publishing Company, 26, p 744.

Mandaville SM 2002. Benthic macroinvertebrates in freshwatersTaxa, tolerance values, metrics and protocols. (Project $H$-1) Soil and Water Conservation Society of Metro Halifax, pp 1-47.

Marwein I and Gupta S 2018. Aquatic insects as indicator of water quality: Astudy on a small stream of Shillong, Meghalaya, Northeast India. Indian Journal of Ecology 45(3): 511-517.

Mc. Cafferty PW and Provonsha VA 1981. Aquatic Entomology. Jones and Bartlett Publishers, London, p 396.

Merritt RW and Cummins KW 1996. An introduction to the aquatic insects of North America. Dubuque, Kendall-Hunt, 3, p 862.

Min JK, Kim YJ and Kong DS 2019. Spatial distribution patterns of benthic macroinvertebrate functional feeding groups by stream size and gradient in Republic of Korea. Journal of FreshwaterEcology 34(1): 715-738.

Morse JC, Yang L and Tian L 1984. Aquatic insects of China useful for Monitoring Water quality. Hohai University Press, Nanjing, 570.

Pandiarajan S, Thambiratnam S, Rajasekaran I and Sivaruban B 2019. Bio-monitoring and detection of water quality using Ephemeroptera, Plecoptera and Trichoptera (EPT) complex in Karanthamalai stream of Eastern Ghats. Indian Journal of Ecology 46(4): 818-822.

Plafkin JL, Babour MT, Porter JG, Gross SK and Hughes RM 1989. Rapid bioasseement protocols for use in Streams and Rivers, Benthic Macroinvertebrates and Fish. EPA/444/4-89/001, Office of Water Regulations and Standards, U. S. Environmental Protection Agency, Washington, DC, p411.

Popoola KOK, Otalekor A 2011. Analysis of aquatic insects' communities of Awba Reservoir and its physico-chemical properties. Research Journal of Environmental and Earth Sciences 3(4): 422-428.

Pringle CM, Naiman RJ, Bretschko G, Karr JR, Oswood MW, Webster JR, Welcomme RL and Wintervourn MJ 1988. Patch dynamics in lotic system: The stream as a mosaic. Journal of the North American Benthological Society 7: 503-524.

Resh VH and Rosenberg DM 1984. The ecology of aquatic insects. Praeger Publishers, New York, pp 625. 
Solanki R and Shukla A 2015. Aquatic insect for biomonitoring freshwater ecosystem: A report. International Journal of Science and Research 6: 2056-2058.

Subramanian KA and Sivaramakrishnan KG 2007. Aquatic insects for biomonitoring freshwater ecosystems: A methodology manual. Asoka Trust for Research in Ecology and Environment (ATREE), Bangalore, India, p 31.

Received 20 October, 2021; Accepted 28 December, 2021
Wahizatul AA, Long SH and Ahmad A 2011. Composition and distribution of aquatic insect communities in relation to water quality in two fresh water streams of Hulu Terengganu, Terengganu. Journal of Sustainability Science and Management 6(1): 148-155.

Yule MC and Sen HY 2004. Freshwater Invertebrates of the Malaysian Region. Akademi Sains, Malaysia. 